\title{
A Study on Profile Characteristics of Rural Young Agri Entrepreneurs
}

\author{
G. Shivacharan $^{1 *}$, V. Sudharani ${ }^{1}$, R. Vasantha $^{1}$ and K. Supriya ${ }^{2}$ \\ ${ }^{1}$ Department of Agricultural Extension, ${ }^{2}$ Department of Statistics and Mathematics, Professor \\ Jayashankar Telangana State Agricultural University, College of Agriculture, \\ Rajendranagar, Hyderabad - 500030, Telangana, India \\ *Corresponding author
}

\begin{tabular}{|c|c|}
\hline & A B S T R A C T \\
\hline & \multirow{8}{*}{$\begin{array}{l}\text { The present study was conducted in Nizamabad and Karimnagar districts of Andhra } \\
\text { Pradesh to study the profile of rural young agri entrepreneurs. Total } 120 \text { respondents were } \\
\text { randomly selected for the study and interviewed. Most of the respondents were late young } \\
\text { aged }(38.33 \%) \text {, had college and above level education }(65.84 \%) \text {, had not undergone any } \\
\text { training }(78.33 \%) \text {, within training undergone majority }(65.38 \%) \text { of them had only } \\
\text { knowledge based training, low entrepreneurial experience }(41.67 \%) \text {, manufacturing } \\
\text { entrepreneurial activity }(52.50 \%) \text {, micro scale of operation }(67.50 \%) \text {, sole proprietorship } \\
\text { ownership status (55.83\%), low extension contact (41.67\%), nonofficial position }(40.83 \%) \text { ) } \\
\text { and official position }(40.00 \%) \text { in one or more organizations, medium information seeking } \\
\text { behaviour (50.83\%), high economic motivation ( } 43.33 \%) \text {, low family support }(42.50 \%) \text {, } \\
\text { medium financial support }(37.50 \%) \text {, seasonal raw material supply }(77.50 \%) \text {, whole sale } \\
\text { market for their product }(85.83 \%) \text { and outside the village market }(85.83 \%) \text {. }\end{array}$} \\
\hline Keywords & \\
\hline $\begin{array}{l}\text { Agri entrepreneurs, } \\
\text { Profile. }\end{array}$ & \\
\hline Article Info & \\
\hline Accepted: & \\
\hline 04 September 2017 & \\
\hline $\begin{array}{l}\text { Available Online: } \\
10 \text { November } 2017\end{array}$ & \\
\hline & \\
\hline
\end{tabular}

\section{Introduction}

Large population of India is dependent on agriculture for their livelihood. But Indian agriculture is facing the challenge of low productivity with large number of disguised unemployed people. Today's knowledge based economy is fertile ground for entrepreneurs, in India. It is rightly believed that India has an extraordinary talent pool with virtually limitless potential to become entrepreneurs. Therefore, it is important to get committed to creating the right environment to develop successful entrepreneurs. To achieve this, India must focus on inculcating entrepreneurial culture in the country. Recent interest in agricultural development coupled with the problems of poverty and unemployment and opening of markets has brought the concept of rural agri entrepreneurship to the fore.

\section{Materials and Methods}

In the present study Ex-post facto research design was followed. According to Kerlinger (1973) ex-post-facto research is a systematic empirical enquiry in which the scientists do not have direct control of influencing (independent) variables, because manifestations have already occurred. Andhra Pradesh state is divided into three regions viz., Telangana, Rayalaseema and Andhra. Telangana region was selected purposively as the investigator hails from this region. Two districts were selected randomly from the 
Telangana region. From the selected districts 6 villages from each district were selected randomly and 10 respondents from each village thus constitute total 120 respondents for the study. An interview schedule was developed for the study and presented in nonsampling areas. The data was collected using standardized interview schedule by personal method. The data was organized, tabulated and classified using qualitative and quantitative classification and subjected to statistical tests. The statistical tools were Frequency and percentage.

\section{Results and Discussion}

\section{Age}

From table 1 it could be concluded that most of the respondents $(38.33 \%)$ were categorized into late young age group followed by young $(26.67 \%)$, moderately young $(23.33 \%)$ and rest of them $(11.67 \%)$ were very young age group. Most of the rural young entrepreneurs were found late young aged.

The reason might be that majority of the young decide to go for self-employment in the event of failure to get organized employment, which takes considerably more time. Besides idea generation, incubation, establishment and running successfully of an enterprise takes quite a long period. Hence majority of the respondents were from late young age group.

\section{Education}

From table 1 it could be concluded that majority of the respondents had college level and above education $(65.84 \%)$ and rest of them had high school education (34.16\%). Education plays a major role in social and economic development of youth. This situation may be due to more awareness of rural youth about education. Education or literacy is a prerequisite for efficient management of enterprise, hence more educated youth might be opting to become entrepreneurs.

\section{Training undergone}

From table 1 it could be concluded that majority of the respondents $(78.33 \%)$ did not undergone any training and rest of them $(21.67 \%)$ had undergone training. The probable reason for not getting trained might be lack of entrepreneurial development programmes (EDP's) related to agri enterprises being organized by MSME development institutes and respondents inability to access entrepreneurship development initiatives.

Presently agriculture EDP's are organized for agriculture poly technique students and agri graduates under Agri Clinic and Agri Business scheme and most of the EDP programmes organized in the study area are focusing more on non-agricultural enterprises. Another reason may be the young entrepreneurs in rural area were not much conscious about the importance of training to run the enterprises technically with all formal procedures. The respondents might have also perceived that the enterprises run by them are on small scale and doesn't require much formal and institutionalized training. The above findings are in accordance with the findings of Ganeshan (2001), Bhagyalakshmi (2002), Anitha (2003).

Within the respondents who had undergone training, majority $(65.38 \%)$ of the respondents had knowledge based training and rest of them $(34.62 \%)$ had both knowledge and skill based training.

The reason for those who getting trained mostly in knowledge based programmes may be due to lack of facilities to provide skill based trainings at the training centres. 


\section{Entrepreneurial experience}

From table 1 it could be concluded that most of the respondents $(41.67 \%)$ possessed low level entrepreneurial experience followed by very low level (23.33\%), medium (18.33\%) and high level (16.67\%) of entrepreneurial experience. The reason for this might be most of the respondents were young aged and some of them have started career in agri entrepreneurship late. The above finding is in accordance with the finding of Maroo (2005).

\section{Type of enterprise}

From table 1 it could be concluded that most (41.67\%) of the rural youth had taken up commercial seed growing followed by rice mill $(25.00 \%)$, vegetable commission agency $(10.83 \%)$, seed processing $(8.33 \%)$, dairy $(6.67 \%)$, poultry $(4.17 \%)$ and turmeric boilers $(3.33 \%)$. The probable reason for this might be the favorable agro climatic conditions for commercial seed production and high demand for the commercial seed in the study area and also they have an adequate buy back system with seed processing units as it has secured marketing. The Karimnagar district being the largest rice grown districts in the state the rural youth might have opted for running the rice mills.

From table 1 it could be concluded that majority $(52.50 \%)$ of respondents having manufacturing activity followed by processing $(36.67 \%)$ and trade $(10.83 \%)$ related entrepreneurial activity. The reason being was majority of entrepreneurs were commercial seed growers, seed processors including rice mill owners.

From table 1 it could be concluded that majority $(67.50 \%)$ of the respondents having micro enterprises and rest of them had small scale $(32.50 \%)$ enterprises. The reasons being were majority of the entrepreneurs were commercial seed growers and it took less investment in plant and machinery and for operating the existing entrepreneurial activity?

From table 1 it could be concluded that majority $(55.83 \%)$ of the respondents having sole proprietorship status and rest of them were having partnership (44.17\%). The reason being was respondents wanted to be owner of their own entrepreneurial activity and even the investment is also low as in commercial seed production, commission agency, dairy, poultry investment is considerably less as compared to processing activities, hence majority of the enterprises were micro enterprises.

\section{Extension contact}

From table 1 it could be concluded that most $(31.67 \%)$ of the respondents had low extension contact followed by medium $(30.83 \%)$, very low $(20.00 \%)$ and high $(17.50 \%)$ extension contact. The reasons might be that each type of enterprise requires specific contacts for running their enterprise successfully. In case of the commercial seed growers they had contact with the inspection officer of that particular private seed company only for all agricultural aspects. Hence they do not have contacts with other extension agencies. The above finding is in partial conformity with the finding of Anitha (2004).

\section{Socio political participation}

From table 1 it could be concluded that 40.84 per cent of the rural youth had non official position in socio political organization, 40.00 per cent of the rural youth had official position in one or more organization, 10 per cent of the rural youth had official position in social/ political/ formal committees and rest of them $(9.16 \%)$ had involvement in community work as a member. 
Table.1 Distribution of rural young agri entrepreneurs according to their profile characters

\begin{tabular}{|c|c|c|c|}
\hline S. No. & Category & Frequency & Percentage (\%) \\
\hline \multicolumn{4}{|l|}{ Age } \\
\hline 1 & Very young & 14 & 11.67 \\
\hline 2 & Young & 32 & 26.67 \\
\hline 3 & Moderately young & 28 & 23.33 \\
\hline 4 & Late young & 46 & 38.33 \\
\hline \multicolumn{4}{|c|}{ Education } \\
\hline 1 & Illiterate & 0 & 0 \\
\hline 2 & Functionally literate & 0 & 0 \\
\hline 3 & Primary school & 0 & 0 \\
\hline 4 & Middle & 0 & 0 \\
\hline 5 & High & 41 & 34.16 \\
\hline 6 & College level and above & 79 & 65.84 \\
\hline \multicolumn{4}{|c|}{ Training undergone } \\
\hline 1 & Undergone training & 26 & 21.67 \\
\hline 2 & Not undergone training & 94 & 78.33 \\
\hline \multicolumn{4}{|c|}{ Type of training } \\
\hline 1 & Knowledge based & 17 & 65.38 \\
\hline 2 & Skill based & 0 & 00.00 \\
\hline 3 & Both knowledge and skill based & 9 & 34.62 \\
\hline
\end{tabular}

\begin{tabular}{|c|c|c|c|}
\hline \multicolumn{4}{|c|}{ Entrepreneurial experience } \\
\hline 1 & Very low & 28 & 23.33 \\
\hline 2 & Low & 50 & 41.67 \\
\hline 3 & Medium & 22 & 18.33 \\
\hline 4 & High & 20 & 16.67 \\
\hline \multicolumn{4}{|c|}{ Type of enterprise } \\
\hline 1 & Seed processing & 10 & 8.33 \\
\hline 2 & Rice mill & 30 & 25.00 \\
\hline 3 & Dairy & 8 & 6.67 \\
\hline 4 & Poultry & 5 & 4.17 \\
\hline 5 & Vegetable commission agency & 13 & 10.83 \\
\hline 6 & Commercial seed production & 50 & 41.67 \\
\hline 7 & Turmeric boiling unit & 4 & 3.33 \\
\hline \multicolumn{4}{|c|}{ Entrepreneurial activity } \\
\hline 1 & Manufacturing & 63 & 52.50 \\
\hline 2 & Processing & 44 & 36.67 \\
\hline 3 & Service & 0 & 0 \\
\hline 4 & Trade & 13 & 10.83 \\
\hline \multicolumn{4}{|c|}{ Scale of operation } \\
\hline 1 & Micro & 81 & 67.50 \\
\hline
\end{tabular}




\begin{tabular}{|c|c|c|c|}
\hline 2 & Small & 39 & 32.50 \\
\hline 3 & Medium & 0 & 0 \\
\hline \multicolumn{4}{|c|}{ Ownership status } \\
\hline 1 & Solo proprietorship & 67 & 55.83 \\
\hline 2 & Partnership & 53 & 44.17 \\
\hline 3 & Joint venture & 0 & 00.00 \\
\hline \multicolumn{4}{|c|}{ Extension contact } \\
\hline 1 & Very low & 28 & 23.33 \\
\hline 2 & Low & 50 & 41.67 \\
\hline 3 & Medium & 22 & 18.33 \\
\hline 4 & High & 20 & 16.67 \\
\hline \multicolumn{4}{|c|}{ Sociopolitical participation } \\
\hline 1 & $\begin{array}{|lllll|}\begin{array}{l}\text { Non official position } \\
\text { organization. }\end{array} & \text { in socio political } \\
\end{array}$ & 49 & 40.83 \\
\hline 2 & Official position in one or more organization. & 48 & 40.00 \\
\hline 3 & $\begin{array}{l}\text { Official position in social/ political/ formal } \\
\text { committees. }\end{array}$ & 12 & 10.00 \\
\hline 4 & $\begin{array}{l}\text { Financial contribution or raising funds for } \\
\text { community work. }\end{array}$ & 0 & 0 \\
\hline 5 & Involvement in community work as a member. & 11 & 9.17 \\
\hline 6 & Participation in any extension activity. & 0 & 0 \\
\hline
\end{tabular}

\begin{tabular}{|c|c|c|c|}
\hline \multicolumn{4}{|c|}{ Information seeking behaviour } \\
\hline 1 & Very low & 12 & 10.00 \\
\hline 2 & Low & 30 & 25.00 \\
\hline 3 & Medium & 61 & 50.83 \\
\hline 4 & High & 17 & 14.17 \\
\hline \multicolumn{4}{|c|}{ Economic motivation } \\
\hline 1 & Very low & 5 & 4.17 \\
\hline 2 & Low & 24 & 20.00 \\
\hline 3 & Medium & 39 & 32.50 \\
\hline 4 & High & 52 & 43.33 \\
\hline \multicolumn{4}{|c|}{ Family support } \\
\hline 1 & Very low & 24 & 20.00 \\
\hline 2 & Low & 51 & 42.50 \\
\hline 3 & Medium & 37 & 30.83 \\
\hline 4 & High & 8 & 6.67 \\
\hline \multicolumn{4}{|c|}{ Financial support } \\
\hline 1 & Very low & 9 & 7.50 \\
\hline 2 & Low & 36 & 30.00 \\
\hline 3 & Medium & 45 & 37.50 \\
\hline 4 & High & 30 & 25.00 \\
\hline
\end{tabular}




\begin{tabular}{|c|c|c|c|}
\hline \multicolumn{4}{|c|}{ Raw material supply } \\
\hline 1 & Seasonal (3 times/ yr.) & 93 & 77.50 \\
\hline 2 & Regular (>3 times/ yr.) & 27 & 22.50 \\
\hline \multicolumn{4}{|c|}{ Market for product } \\
\hline 1 & Wholesale/ Retail & 103 & 85.83 \\
\hline 2 & Both (whole sale and retail). & 17 & 14.17 \\
\hline \multicolumn{4}{|c|}{ Location of market } \\
\hline 1 & Within village & 4 & 3.33 \\
\hline 2 & Outside village & 103 & 85.84 \\
\hline 3 & Both & 13 & 10.83 \\
\hline
\end{tabular}

The reason for this might be in case of commercial seed growing there was no organization where as in case of rice mill and dairy enterprises there were organizations for the members. These results might be due to lack of interest and motivation participating in social organization and political, community and extension activities.

\section{Information seeking behavior}

From table 1 it could be concluded that majority of the respondents had medium level of information seeking behavior (50.83\%) followed by low $(25.00 \%)$ high $(14.17 \%)$ and very low (10.00\%) information seeking behaviour. The low level of extension contact for enterprise management and less awareness of information sources regarding enterprises management might have contributed the medium level of information seeking behavior. The finding is in accordance with Chaitanya (2004) and Suresh (2004).

\section{Economic motivation}

From table 1 it could be concluded that most $(43.33 \%)$ of the respondents had high economic motivation followed by medium $(32.50 \%)$, low $(20.00 \%)$ and very low $(4.17 \%)$ economic motivation. It indicates that the selected enterprises were much profitable and yield immediate income to meet their needs. Besides motivation and need for achievement are generally high among entrepreneurs. The finding is in partial conformity with the findings of Bhagyalakshmi et al., (2003) and Chauhan and Patel (2003).

\section{Family support}

From table 1 it could be concluded that most $(42.50 \%)$ of the respondents had low family support followed by medium $(30.83 \%)$, very low $(20.00 \%)$ and high (6.67\%) family support. The reasons for this finding could be most of the youth were having support from their parents with fear of failure, this might be the reason for low family support. For some of respondents the entrepreneurial activity came by succession. The finding is in partial conformity with the finding of Chaitanya (2004).

\section{Financial support}

From table 1 it could be concluded that most $(37.50 \%)$ of the respondents had medium financial support followed by low (30.00\%), high $(25.00 \%)$ and very low $(7.50 \%)$ financial support. Finance plays a vital role in smooth running of any enterprise. The reasons for this might be that the respondents depend on commercial banks and lead bank in the area for finance and now a day's most of the banks are coming forward in giving credit for entrepreneurial activities. There is a minimum support from Govt. and other MSME development agencies also might be a reason for a medium financial support. The finding is in partial conformity with the finding of Chaitanya (2004). 


\section{Marketing facilities}

From table 1 it could be concluded that majority of the respondents had seasonal supply of raw material $(77.50 \%)$ and rest of them had regular in supply of raw material $(22.50 \%)$. As the agriculture is mostly seasonal in nature so agri entrepreneurs plan their production activities according to the season.

From table 1 it could be concluded that majority of the respondents sell their products in wholesale/ retail market $(85.83 \%)$ rest of them had both wholesale and retail marketing $(14.17 \%)$. The reasons might be that the majority of respondents were commercial seed growers who had tie up with the seed companies for their produce and in case of processing enterprises they had tie up with the other seed companies for their products. From table 1 it could be concluded that majority of the respondents sell their products in outside village $(85.83 \%)$ followed by both in village and outside village $(10.83 \%)$ and few of them $(3.33 \%)$ sell their products in village. The reason might be that majority of the respondents sell their produce outside the village because the respondents had tie up with the other seed companies for their produce.

\section{References}

Anitha, B., 2004. A study on entrepreneurial behaviour and market participation of farm women in Bangalore rural district of Karnataka. M.Sc. (Agri.) Thesis. University of Agricultural Sciences, Bangalore.

Anitha, M., 2003. Astudy on empowerment of women entrepreneurs in Rangareddy district. M.Sc. (Ag.) Thesis. Acharya N.G.
Ranga Agricultural University, Hyderabad, India.

Bhagyalakshmi, K., 2002. A critical study on micro enterprise management by rural women in Rangareddy district of Andhra Pradesh. Ph.D Thesis. Acharya N.G. Ranga Agricultural University, Hyderabad, India.

Bhagyalakshmi, K., Rao, V.G.K and Reddy, M.S. 2003. Profile of the rural women micro-entrepreneurs. Journal of Research. Acharya N.G. Ranga Agricultural University, Hyderabad, 31 (4): 51-54.

Chaitanya, K.M.S., 2004. A study on tribal women entrepreneurs in high altitude tribal zone of Andhra Pradesh. Ph.D. Thesis. Acharya N G Ranga Agricultural University, Hyderabad, India.

Chauhan, N.B., and Patel, R.C. 2003. Entrepreneurial uniqueness of poultry entrepreneurs. Rural India. 66 (12): 236239.

Ganeshan, G., 2001. Entrepreneurship Development. Kisan World. 28 (6): 5051.

Kerlinger, F.N., 1973. Foundations of behavioral research. Holt, Rinehart and Winston. New York.

Maroo, K., 2005. Knowledge and adoption of improved dairy management practices by women dairy farmers in Dharwad district. M.Sc. Thesis. University of Agricultural Sciences, Dharwad.

Suresh, 2004. Entrepreneurial behaviour of milk producers in Chittoor district of Andhra Pradesh - a critical study. M.V.Sc. Thesis. Acharya N.G. Ranga Agricultural University, Hyderabad, India.

\section{How to cite this article:}

Shivacharan, G., V. Sudharani, R. Vasantha and Supriya, K. 2017. A Study on Profile Characteristics of Rural Young Agri Entrepreneurs. Int.J.Curr.Microbiol.App.Sci. 6(11): 252-258. doi: https://doi.org/10.20546/ijcmas.2017.611.030 